\title{
PERUBAHAN SIFAT KIMIA TANAH DAN HASIL JAGUNG PADA INSEPTISOL DENGAN PEMBERIAN KOMPOS
}

\author{
Halasan $^{1}$, Anandyawati ${ }^{* *}$, Hasanudin ${ }^{1}$, Riwandi ${ }^{1}$ \\ Program Studi Agroekoteknologi, Fakultas Pertanian, Universitas Bengkulu \\ Program Studi Ilmu Tanah, Fakultas Pertanian, Universitas Bengkulu \\ Corresponding Author : anandyawati@yahoo.co.id
}

\begin{abstract}
[CHANGE IN SOIL CHEMICAL CHARACTERISTICS AND YIELD OF MAIZE IN AN INCEPTISOL AS AMENDED WITH COMPOST]. Vast area of inceptisol in Indonesia is a potential natural resource for improving the domestic maize production. The amendment of organic material is expected to make correction on the fertility problem inherent in the soil. Objective of this study was to determine the optimum dose of compost for some soil chemical properties and maize performances. The doses of compost consisted of $0,2.5,5,7.5,10$, and 12.5 ton/ha a were allotted randomly on the experimental plots according to completely randomized design with three replications. Observations were made on the exchangeable Aluminum (Al-dd), pH, organic carbon, water content, plant height, unhusked and husked ear weight, and grain yield. Analysis of variance showed that the dose of compost had significant $(\mathrm{P} \leq 0.05)$ effects on $\mathrm{pH}$ and $\mathrm{C}$-organic in soil. Giving compost at a dose about 12.5 ton/ha could increase the $\mathrm{pH}$ about 4.9 , whereas giving compost at a dose about 10 ton/ha could increase $\mathrm{C}$-organic about $3.09 \%$. In other hand, the giving of compost with various dose did not give significantly $(\mathrm{P}>0.05)$ affect towards Aluminium (Al-dd), $\mathrm{pH}, \mathrm{C}$-organic, water content, height of plants, weight of without husk, weight of cob with husk, weight of dry corn beans. The highest grain yield $(2,415.75 \mathrm{~kg} / \mathrm{ha})$ was observed on compost applied at dose $12.5 \mathrm{ton} / \mathrm{ha}$.
\end{abstract}

Keyword: exchangeable aluminum, organic carbon, husked ear, grain yield

\begin{abstract}
ABSTRAK
Inseptisol yang ketersediaanya di Indonesia sangat luas merupakan potensi sumberdaya alam yang dapat dimanfaatkan untuk meningkatkan produksi jagung di dalam negeri. Penambahan bahan organik diharapkan dapat memperbaiki tingkat kesuburan yang terdapat pada jenis tanah tersebut. Penelitian ini bertujuan untuk menentukan dosis pupuk kompos optimal untuk berbagai sifat kimia tanah dan hasil jagung. Dosis kompos yang terdiri atas $0,2,5,5,7,5,10$, dan 12,5 ton/ha dialokasikan secara acak pada petak-petak percobaan berdasarkan rancangan acak lengkap dengan tiga ulangan. Pengamatan dilakukan terhadap Aluminium dapat ditukar (Al-dd), pH, C-organik, kadar air, tinggi tanaman, berat tongkol tanpa kelobot, berat tongkol berkelobot dan berat pipilan kering. Hasil analisis keragaman menunjukkan bahwa dosis pupuk kompos berpengaruh nyata $(\mathrm{P} \leq 0,05)$ terhadap $\mathrm{pH}$ dan $\mathrm{C}$-organik tanah. Pemberian pupuk kompos pada dosis 12,5 ton/ha dapat meningkatkan $\mathrm{pH}$ sebesar 4,9 sedangkan pada dosis 10 ton/ha dapat meningkatkan Corganik sebesar 3,09\%. Pupuk kompos pada berbagai dosis berpengaruh tidak nyata $(\mathrm{P}>0,05)$ terhadap Al-dd, kadar air, tinggi tanaman, berat tongkol berkelobot, berat tongkol tanpa kelobot dan berat pipilan kering. Hasil tertinggi berat pipilan kering rata-rata $2415,75 \mathrm{~kg}$ dihasilkan pada pemberian kompos dengan dosis 12,5 ton/ha.
\end{abstract}

Kata kunci: Al-dd, C-organik, tongkol berkelobot, hasil biji pipilan 


\section{PENDAHULUAN}

Tanaman jagung (Zea mays L.) merupakan tanaman serealia yang menjadi sumber karbohidrat terpenting ke dua setelah beras. Kebutuhan jagung Indonesia setiap tahun terus mengalami peningkatan (Nasution, 2004). Data BPS (2012) menunjukkan bahwa kebutuhan jagung meningkat sampai dengan $8 \%$ dari total kebutuhan jagung tiap tahun. Pemenuhan kebutuhan ini masih terkendala dengan produksi rata-rata jagung yang masih rendah. Rendahnya produksi rata-rata jagung disebabkan oleh adanya alih fungsi lahan, terbatasnya ketersediaan lahan-lahan produktif serta menurunkan kualitas tanah-tanah pada lahan pertanian.

Produksi jagung Indonesia pada tahun 2014 mencapai 19.38 juta ton pipilan kering. Indonesia mengimpor jagung 1.03 juta ton pada tahun 2015 (BPS, 2014). Upaya peningkatan produksi jagung di dalam negeri diarahkan pada pemanfaatan lahanlahan marjinal karena terbatasnya lahan subur. Salah satu lahan marjinal yang memiliki potensi adalah tanah Inceptisol. Inceptisol adalah ordo tanah dengan waktu pelapukan yang tergolong baru dengan salah satu cirinya adalah terdapatnya horizon kambik pada kedalaman $100 \mathrm{~cm}$.

Luas Inceptisol di Indonesia mencapai 70.52 juta ha atau 37.3\% dari wilayah Indonesia dan di Provinsi Bengkulu seluas 894.073 ha (Puslittanak, 2000). Lahan-lahan Inceptisol ini, terutama di Provinsi Bengkulu masih belum dimanfaatkan untuk pertanian. Kendala utama Inceptisol untuk lahan pertanian adalah $\mathrm{pH}$ tanah yang rendah atau sangat masam, kadar N, P, K dan bahan organik yang rendah. Salah satu upaya yang dilakukan untuk memperbaiki Inceptisol adalah dengan pemberian pupuk kompos (Soepardi, 1982).

Pupuk kompos merupakan pupuk yang berasal dari sisa biomassa tanaman dan hewan yang mengalami proses pengomposan dalam waktu tertentu hingga membentuk humus tanah yang stabil (Tambone et al., 2010). Abdel \& Rahman (2009) menyatakan bahwa pupuk kompos dapat menyuburkan tanah karena pupuk kompos mampu meningkatkan aktivitas jasad hidup tanah, memperbaiki struktur tanah, kadar lengas tanah, kapasitas tukar kation, stabilitas agregat tanah dan infiltrasi air tanah. Pemberian pupuk kompos juga meningkatkan ketersediaan fosfor dan mempertahankan produktivitas tanah (Mahmud \& Sudiarso, 2002).

Hasil penelitian Setyowati et al. (2009) menunjukkan bahwa pemberian pupuk organik dalam tanah dapat memperbaiki sifat kimia tanah. Penelitian Lahudin et al. (2010) menunjukkan bahwa pupuk organik juga dapat meningkatkan $\mathrm{pH}$ tanah, menurunkan kadar $\mathrm{Al}$, serta meningkatkan ketersediaan unsur hara makro dan mikro. Selain itu, penelitian Sumarwoto (2014) juga menunjukkan bahwa pemberian pupuk kandang dapat menurunkan kadar Al-dd yang tinggi serta menaikkan $\mathrm{pH}$ tanah dan unsur hara yang rendah. Berdasarkan uraian di atas, penelitian pemanfaatan pupuk kompos terhadap perbaikan sifat fisik dan kimia Inceptisol dan peningkatan hasil tanaman jagung (Zea mays L.) sangat penting untuk dilakukan.

\section{METODE PENELITIAN}

Penelitian ini dilaksanakan di Desa Kandang Mas, Kelurahan Betungan, Kecamatan Selebar Kota Bengkulu pada bulan Mei sampai dengan Agustus 2015. Penelitian dilakukan pada tanah Inceptisol. Bahan utama yang digunakan antara lain benih jagung BISI2 dan bahan-bahan untuk membuat kompos antara lain : jerami padi, kipahit (Thitonia diversifolia), tusuk konde (Widelia trilobata), arang sungsang (Asystasia gangetica), daun kering, sekam padi, kotoran kambing, gula pasir, EM-4, dan pupuk NPK. Alat-alat yang diguna kan terdiri atas cangkul, sabit, parang, meteran, timbangan analitik, bambu, selang air, gembor, ember, tugal, dan alat tulis.

Penelitian ini menggunakan Rancangan Acak Lengkap (RAL) dengan perlakuan dosis pupuk kompos yang terdiri atas enam taraf, yaitu : 0 ton/ ha $(0 \mathrm{~kg} /$ petak $), 2.5 \mathrm{ton} / \mathrm{ha}$ (12 g/petak), 5 ton/ha (24 kg/petak), 7.5 ton/ha (36 kg/petak), 10 ton/ha (48 kg/petak), dan 12.5 ton $/$ ha $(60 \mathrm{~kg} /$ petak). Setiap satuan percobaan diulang 4 kali sehingga jumlahnya 24 satuan percobaan. Penelitian ini terdiri atas beberapa tahap, yaitu : (1) Pembuatan pupuk kompos, (2) persiapan media tanam dan penanaman, (3) pengamatan variabel pertumbuhan dan analisis tanah.

Pembuatan pupuk kompos dilakukan di Desa Medan Baru, Kecamatan Muara Bangkahulu, Kota Bengkulu. Bahan pupuk kompos berupa tanaman yang kaya dengan unsur hara, seperti arang sungsang (Asystasia gangetica), kipahit (Thitonia diversifolia), tusuk konde (Widellia trilobata), daun kering, kotoran kambing, sekam dan jerami padi. Semua bahan tersebut dicacah sepanjang 1-2 cm, dimasukkan ke dalam bak tempat pengomposan kemudian disiram larutan. Larutan tersebut dibuat dengan melarutkan EM-4 $1 \mathrm{~L}$, urea $1 \mathrm{~kg}$ dan gula pasir 1 $\mathrm{kg}$ dalam air bersih $15 \mathrm{~L}$ yang diinkubasi selama 24 jam. Larutan tersebut kemudian disiramkan secara merata pada bahan-bahan pupuk kompos. Tutup rapat bak pengomposan (inkubasi) dan lakukan pengamatan berkala (setiap 1 minggu hingga pupuk kompos menjadi matang). Panen pupuk kompos dilakukan setelah pupuk kompos matang (setelah 1,5 bulan inkubasi) dengan ciri-ciri kompos sebagai berikut: warna hitam, tidak berbau, $\mathrm{pH}$ netral $(\mathrm{pH} 7$ -8), kadar lengas cukup (50-60\%), nisbah jumlah bahan kasar dan halus yang seimbang, dan bersifat remah. 
Persiapan media tanam dilakukan dengan membuat petakan-petakan dan ditambahkan kompos matang dengan dosis sesuai perlakuan. Penanaman benih jagung dilakukan dengan memasukkan 2 benih jagung ke dalam lubang tanam dengan jarak tanam $30 \mathrm{~cm}$ x $80 \mathrm{~cm}$ pada polybag yang telah dipersiapkan, sehingga didapatkan 200 tanaman per petak. Penyulaman tanaman jagung dilakukan 1 minggu setelah tanam dengan menanam kembali benih jagung pada lubang tanam yang tidak tumbuh agar semua tanaman dapat tumbuh merata. Untuk penjarangan tanaman (dari dua tanaman dalam satu lubang menjadi satu tanaman) dilakukan dengan memotong satu tanaman setelah tanaman tumbuh merata.

Perawatan dilakukan dengan penyiraman rutin, pembumbunan dan pengendalian organisme pengganggu tanaman (OPT). Penyiraman dilakukan secara rutin pagi dan sore hari. Pembumbunan dilakukan untuk memperkokoh batang jagung agar tidak mudah rebah dan menutup akar yang muncul di atas permukaan tanah. Pembumbunan dilakukan pada saat tanaman berumur 2 sampai 8 minggu. Pembumbunan dilakukan dengan membalik tanah di sebelah kanan dan kiri barisan tanaman dengan cangkul, kemudian ditimbun di barisan tanaman sehingga terbentuk guludan yang memanjang. Pengendalian organisme pengganggu tanaman (OPT) dilakukan terhadap gulma, hama, dan penyakit yang menyerang tanaman jagung. Gulma yang ada pada lahan dikendalikan dengan melakukan penyiangan pada petak yang ditumbuhi gulma. Untuk hama seperti belalang, dilakukan pengendalian secara manual, yaitu mengambil hama yang menyerang dan dibuang jauh dari lahan percobaan. Untuk penyakit, dikendalikan dengan menggunakan bahan-bahan pestisida organik saat terlihat adanya gejala serangan.

Panen dilakukan setelah populasi tanaman mencapai 90\% stadium masak yang dicirikan dengan warna dan keadaan biji kuning, kelobot berwarna kekuningan dan pengisian biji sempurna. Perubahan warna terjadi pada rambut tongkol dari putih menjadi coklat dan jika tongkol dipegang terasa bijinya sudah penuh. Pemanenan dilakukan dengan cara mematahkan tongkol pada batang jagung.

Pengamatan dilakukan secara langsung di lapangan dan analisis tanah di laboratorium. Pengamatan lapangan dilakukan pada tanaman yang terpilih sebagai sampel. Variabel pengamatan antara lain : (a) tinggi tanaman (cm) diukur dengan meteran dari permukaan tanah sampai dengan titik tumbuh tinggi tanaman (setiap minggu setelah tanam sampai dengan $75 \%$ tanaman mulai memasuki fase generatif), (b) bobot tongkol berkelobot dan bobot tongkol tanpa kelobot (g) ditimbang pada saat panen berdasarkan bobot tiap tongkol tanaman sampel dengan menggunakan timbangan analitik, dan (c) bobot pipilan kering (g) yang ditimbang saat panen. Analisis tanah di laboratorium terdiri atas : C-organik tanah (Walkley \& Black), $\mathrm{pH}\left(\mathrm{H}_{2} \mathrm{O}\right)$ ( $\mathrm{pH}$ meter), Al-dd (Ekstrak KCl $1 \mathrm{M})$, dan kadar lengas (Gravimetri).

Data pengamatan tanaman dan tanah dianalisis keragamannya secara statistik menggunakan sidik ragam pada taraf $5 \%$. Bila sidik ragam menunjukkan perbedaan yang nyata, analisis statistik dilanjutkan dengan polinominal ortogonal (Gomez \& Gomez, 1984).

\section{HASIL DAN PEMBAHASAN}

Awal penelitian, persentase daya tumbuh benih jagung hanya mencapai $30 \%$, kemudian dilakukan penyulaman hingga persentase daya tumbuh benih jagung mencapai 95\%. Pengamatan lapangan terkait variabel tanaman jagung dilakukan 3 minggu setelah tanam. Selama penelitian berlangsung banyak permasalahan yang terjadi, antara lain: musim kemarau yang panjang sehingga tanaman jagung kekurangan air (rata-rata curah hujan turun selama penelitian 100.9 $\mathrm{mm} /$ bulan), dan serangan hama kutu daun pada beberapa petak percobaan. Sehingga pada 4 minggu setelah tanam terlihat pertumbuhan tanaman jagung tidak merata karena heterogenitas tanah dan lingkungan yang cukup tinggi.

Analisis laboratorium menunjukkan bahwa tanah pada lahan penelitian ini mempunyai sifat sebagai berikut: tekstur liat berpasir (sandy clay loam), $\mathrm{pH}$ $\left(\mathrm{H}_{2} \mathrm{O}\right)$ 4,6 (masam), kadar C-organik 2,65\%, dan Al-dd 2,34 cmol(+)/kg. Berdasarkan data tersebut tanah ini tergolong tanah yang kurang subur. Hasil sidik ragam menunjukkan bahwa pupuk kompos nyata pengaruhnya $(\mathrm{P} \leq 0,05)$ terhadap $\mathrm{pH}\left(\mathrm{H}_{2} \mathrm{O}\right)$ dan $\mathrm{C}$ organik tanah, sedangkan terhadap variabel tanah yang lain dan hasil tanaman jagung berpengaruh tidak nyata $(\mathrm{P}>0,05)$.

Pemberian pupuk kompos terhadap rata-rata $\mathrm{pH}$ $\left(\mathrm{H}_{2} \mathrm{O}\right)$ tanah pada setiap perlakuan pupuk kompos menunjukkan pengaruh yang nyata (Gambar 1). Pada pupuk kompos dosis 2,5 ton/ha menunjukkan $\mathrm{pH}$ $\left(\mathrm{H}_{2} \mathrm{O}\right)$ yang tertinggi $(4,7)$, sedangkan pada pupuk kompos dosis 0 ton/ha dan 5 ton/ha cenderung mengalami penurunan. Kemudian terjadi peningkatan pada pupuk kompos dosis 7,5 ton/ha dan 12,5 ton/ha. Penambahan pupuk kompos yang telah matang (telah mengalami proses dekomposisi) biasanya menyebabkan peningkatan $\mathrm{pH}$ tanah, karena asam-asam organik bahan kompos telah dilepaskan selama proses dekomposisi. Penurunan $\mathrm{pH}\left(\mathrm{H}_{2} \mathrm{O}\right)$ tanah dapat disebabkan porositas tanah inceptisol yang baik sehingga air masuk ke dalam lapisan tanah bawah, akibatnya tanah lapis olah kekurangan air. Kekurangan air di dalam lapis olah tanah menyebabkan konsentrasi kation $\mathrm{H}^{+}$ tinggi atau $\mathrm{pH}\left(\mathrm{H}_{2} \mathrm{O}\right)$ tanah rendah. Ketika hujan turun, pupuk kompos terbawa oleh air melalui infiltrasi ke dalam tanah sehingga pupuk kompos 
yang diberikan tidak bereaksi dengan tanah secara sempurna.

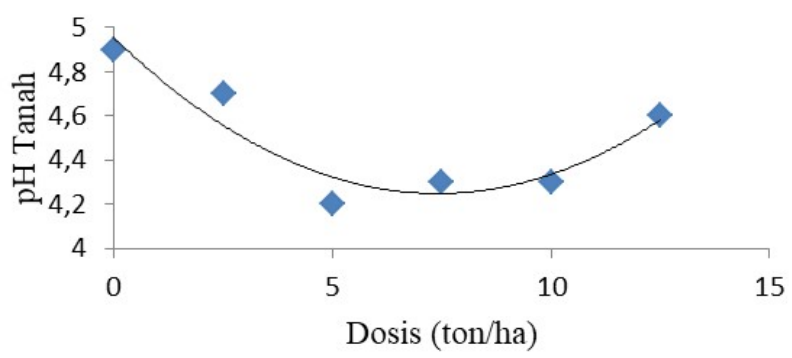

Gambar 1. Pengaruh dosis pupuk kompos terhadap $\mathrm{pH}$ $\left(\mathrm{H}_{2} \mathrm{O}\right)$ tanah

Pupuk kompos dapat meningkatkan $\mathrm{pH}\left(\mathrm{H}_{2} \mathrm{O}\right)$ tanah, karena adanya proses amonifikasi residu $\mathrm{N}$ dalam tanah (Mokolobate \& Haynes, 2001). Peningkatan $\mathrm{pH}\left(\mathrm{H}_{2} \mathrm{O}\right)$ tanah terjadi karena ada pelepasan kation basa dari dekomposisi bahan organik pupuk kompos sehingga meningkatkan konsentrasi $\mathrm{OH}^{-}$.

Hasil analisis menunjukkan bahwa kontribusi pupuk kompos terhadap kadar C-organik tanah ratarata sebesar $66 \%$. Dosis pupuk kompos optimum 7,1 ton/ha menghasilkan kadar C-organik tanah yang tertinggi rata-rata $2,8 \%$.

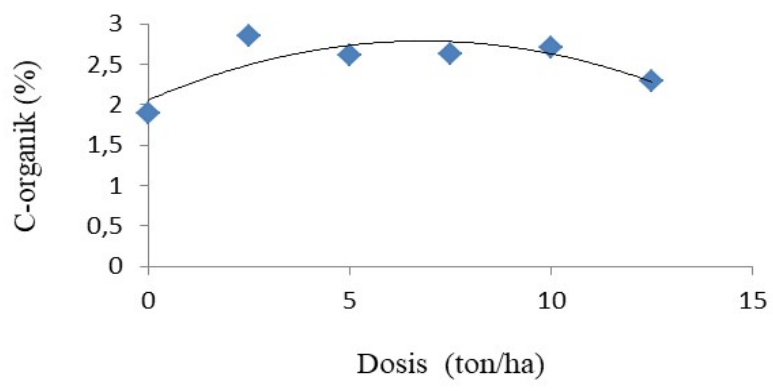

Gambar 2. Pengaruh dosis pupuk kompos terhadap C organik tanah

Berdasarkan sidik ragam terlihat bahwa dosis pupuk kompos berpengaruh nyata terhadap $\mathrm{C}$-organik tanah. Peningkatan kadar C-organik tanah terjadi karena pupuk kompos melepaskan C-organik sehingga Corganik dalam tanah meningkat. Pupuk kompos juga memperbaiki agregat tanah dan porositas tanah sehingga kemampuan tanah dalam menyimpan air semakin tinggi.

Kecenderungan $\mathrm{C}$-organik tanah menurun dengan bertambahnya dosis pupuk kompos setelah dosis pupuk kompos 7,1 ton/ha, karena C-organik dari pupuk kompos diambil oleh jasad renik tanah untuk energi. Jasad renik tanah berfungsi merombak bahan organik yang berasal dari pupuk kompos sampai dengan pupuk kompos matang, sehingga C-organik dari pupuk kompos menurun. Setelah bahan organik yang ditambahkan telah terdekomposisi sempurna, mikroba kembali memanfaatkan bahan organik yang ada di dalam tanah. Hal inilah yang menyebabkan kadar $\mathrm{C}$ organik menjadi rendah dibanding kondisi awal tanah.

Hubungan antara dosis pupuk kompos dan kadar Al-dd tanah terlihat pada Gambar 3.

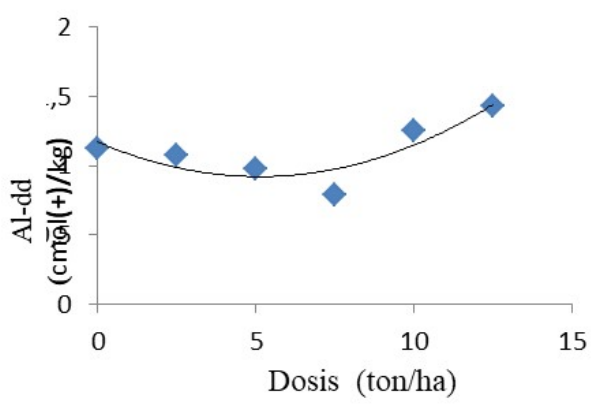

Gambar 3. Pengaruh dosis pupuk kompos terhadap Al-dd tanah

Penurunan kadar Al-dd tanah sampai dengan dosis pupuk kompos 7,5 ton/ha karena asam-asam organik dari pupuk kompos mampu mengikat Al-dd tanah menjadi ikatan Al dengan asam organik kompleks. Pupuk kompos 7,5 ton/ha memberikan kadar Al-dd tanah yang terendah, tetapi penambahan pupuk kompos hingga 12,5 ton/ha memberikan kadar Al-dd yang tertinggi. Selama penelitian berlangsung curah hujan sangat rendah, ketersedian air tanah tidak cukup sehingga mineralisasi pupuk kompos sangat lambat, asam-asam organik yang berasal dari pupuk kompos yang berperan menurunkan Al-dd tidak dapat berjalan secara maksimal. Hal ini sesuai dengan pernyataan Hakim et al. (1986) bahwa air mempunyai fungsi membantu proses pelapukan bahan organik tanah, dan melarutkan unsur hara yang dilepaskan dari pelapukan sehingga dapat diserap tanaman. Rendahnya $\mathrm{pH}$ tanah dapat meningkatkan kadar Al-dd tanah.

Hubungan dosis pupuk kompos terhadap kadar lengas tanah menunjukkan. Ada peningkatan kadar lengas tanah setelah pupuk kompos 10 ton/ha atau lebih (Gambar 4). Hal ini terjadi karena pupuk kompos dengan dosis yang cukup tinggi mampu memperbaiki struktur tanah dan pori tanah. Pupuk kompos menyebabkan air tanah yang dapat disimpan dalam tanah lebih tinggi, kondisi tersebut dapat mengurangi evaporasi bila suhu udara dan radiasi sinar matahari yang tinggi. Kadar air yang diikat oleh bahan organik tanah (pupuk kompos), dapat mengurangi kehilangan air melalui perkolasi dan evaporasi. 


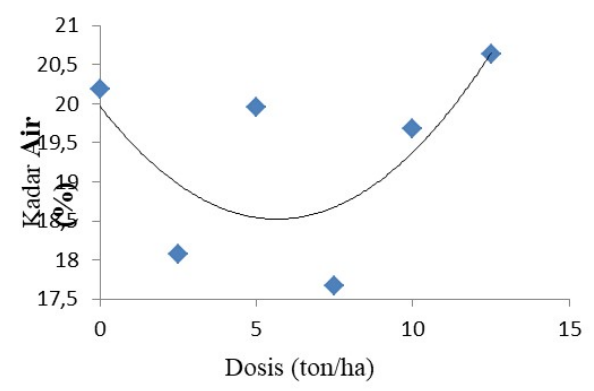

Gambar 4. Pengaruh dosis pupuk kompos terhadap kadar air tanah

Berdasarkan sidik ragam pupuk kompos berpengaruh tidak nyata $(\mathrm{P}>0,05)$ terhadap tinggi tanaman, bobott tongkol berkelobot, bobott tongkol tanpa kelobot dan bobot pipilan kering jagung. Terdapat kecenderungan peningkatan bobot tongkol berklobot (BTK), bobot tongkol tanpa kelobot (BTTK), dan bobot pipilan kering (BPK) tanaman jagung dengan bertambahnya dosis pupuk kompos (Gambar 5).

Bobot tongkol berkelobot (BTK) yang tertinggi (90,1 g/tongkol) dengan dosis pupuk kompos 12,5 ton/ha, sedangkan BTK yang terendah (44,25 g/tongkol) dengan dosis pupuk kompos 2,5 ton/ha. Bobot tongkol berkelobot (BTK) tanaman jagung belum maksimal. Penelitian Utami (2014) memperoleh BTK 184,78 g/ tongkol dengan dosis 18,75 ton/ha. Bobot tongkol tanpa kelobot (BTTK) yang tertinggi $(76,25 \mathrm{~g} /$ tongkol diperoleh pada pupuk kompos 12,5 ton/ha, sedangkan BTTK yang terendah 35,25 $\mathrm{g} /$ tongkol dengan pupuk kompos 2,5 ton/ha.

Bobot pipilan kering (BPK) jagung yang tertinggi 58 $\mathrm{g} /$ tanaman pada pupuk kompos 12,5 ton/ha, sedangkan BPK yang terendah, 24,37 g/tanaman pada pupuk kompos 2,5 ton/ha. Bobot pipilan kering (BTK) tanaman jagung tiap hektar yang tertinggi rata-rata 2,415 ton/ha dengan pupuk kompos 12,5 ton/ha, sedangkan BPK tanaman jagung yang terendah sebesar 1,015 ton/ha dengan pupuk kompos 2,5 ton/ ha. Kurang berhasilnya penelitian ini disebabkan musim kemarau yang panjang selama penelitian. Tanaman jagung adalah tanaman yang peka terhadap kekurangan air. Bila tanaman jagung kekurangan air, maka pertumbuhan tanaman jagung terhambat. Tanaman jagung membutuhkan curah hujan rata-rata $100-250 \mathrm{~mm} /$ bulan, selama penelitian berlangsung curah hujan rata-rata $100,9 \mathrm{~mm} /$ bulan sehingga kebutuhan air kurang mencukupi. Hal ini yang menyebabkan pengaruh pupuk kompos tidak maksimal terhadap pertumbuhan tanaman jagung. Pada kondisi musim kemarau, proses penyerbukan terganggu sehingga mengakibatkan hasil jagung tidak maksimal (Nafziger, 2011). Selanjutnya peneliti yang sama menyatakan bahwa kekurangan air pada saat penyerbukan menyebabkan penurunan hasil biji. Penyerbukan adalah waktu kritis dalam siklus hidup tanaman jagung, yang keberhasilan/kegagalan penyerbukan dan pembentukan biji secara langsung mempengaruhi jumlah biji.

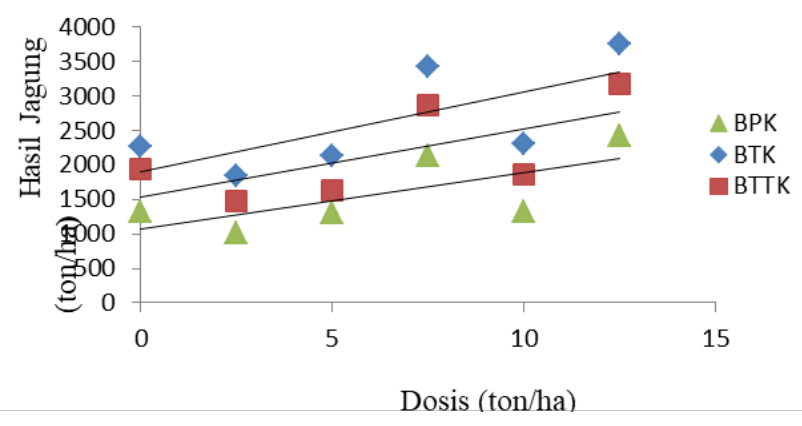

Gambar 5. Pengaruh dosis pupuk kompos terhadap hasil Jagung

Pada minggu ke-1 sampai dengan minggu ke-7, pertumbuhan tinggi jagung lebih tinggi pada pupuk kompos 12,5 ton/ha dari pada perlakuan pupuk kompos yang lain $(10,7,5,5,2,5,0$ ton/ha). Tinggi tanaman jagung yang tertinggi rata-rata $128,5 \mathrm{~cm}$ pada pupuk kompos 12,5 ton/ha. Tinggi tanaman jagung ini belum maksimal bila dibanding dengan rata-rata tinggi tanaman jagung yang bisa mencapai $189 \mathrm{~cm}$ (Gambar 6).

Kendala yang dihadapi tanaman jagung kekurangan air sehingga menurunkan tinggi tanaman, selain itu menurunkan jumlah daun, dan diameter batang (Farooq et al., 2009). Mathius et al. (2001) menyatakan bahwa kekeringan tanaman disebabkan kekurangan pasokan air di daerah sistem perakaran dan kebutuhan air yang berlebihan karena laju evapotranspirasi lebih tinggi daripada laju absorpsi air oleh akar tanaman. Wayah et al. (2004) menyatakan bahwa bila kebutuhan air tidak terpenuhi, maka partumbuhan tanaman terhambat, karena air berfungsi melarutkan unsur hara dan membantu proses metabolisme tanaman jagung. Kurang maksimalnya hasil jagung disebabkan oleh kebutuhan air yang kurang terpenuhi. Tanaman jagung merupakan tanaman yang peka terhadap kekurangan air, jagung menutup stomata pada siang hari bila air kurang tersedia. Hal ini menyebabkan fotosintesis terganggu sehingga berpengaruh terhadap hasil tanaman jagung. Bila laju fotosintesis menurun, maka pertumbuhan tanaman terhambat, karena berkurangnya sumber energi untuk proses pembelahan dan pembesaran sel (Chaves et al., 2003). Selanjutnya dikatakannya bahwa terhambatnya aktivitas pembelahan sel, menyebabkan tidak terjadinya 
penambahan isi sel dan pembelahan sel, sehingga sel-sel tetap mengecil.

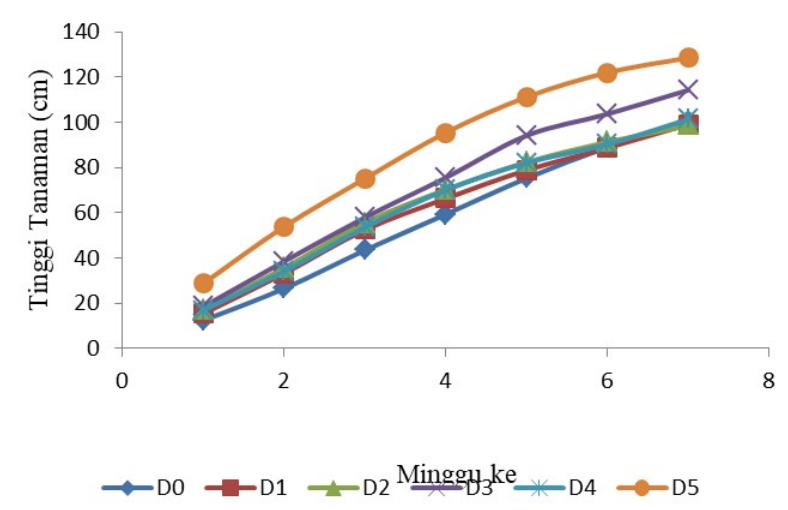

Gambar 6. Pengaruh dosis pupuk kompos terhadap tinggi Tanaman

\section{KESIMPULAN}

Pemberian pupuk kompos pada dosis 12,5 ton/ ha dapat meningkatkan $\mathrm{pH}$ sebesar 4,9 sedangkan pada dosis 10 ton/ha dapat meningkatkan C-organik sebesar 3,09 \%. Pupuk kompos pada berbagai dosis berpengaruh tidak nyata $(\mathrm{P}>0,05)$ terhadap $\mathrm{Al}-\mathrm{dd}$, kadar air, tinggi tanaman, berat tongkol berkelobot, berat tongkol tanpa kelobot dan berat pipilan kering. Hasil tertinggi berat pipilan kering rata-rata 2415,75 $\mathrm{kg}$ dihasilkan pada pemberian kompos dengan dosis 12,5 ton/ha.

\section{UCAPAN TERIMA KASIH}

Penulis mengucapkan terima kasih setinggi-tingginya kepada Direktorat Penelitian dan Pengabdian kepada Masyarakat, Kemenristekdikti, Jakarta yang telah memberikan hibah penelitian kompetensi TA 2015 dengan anggaran DIPA Kemenristekdikti Nomor 23.04.1.673453/2015, tanggal 14 November 2014 dan LPPM Universitas Bengkulu bekerjasama dengan Ditlitabmas Kemristekdikti, Jakarta.

\section{DAFTAR PUSTAKA}

Abdel-Rahman, G. (2009). Impact of compost on soil properties and crop productivity in the Sahel North Burkina Faso. American-Eurasian Journal of Agricultural and Environmental Science, 6(2), 220-226.

BPS. (2012). Data Strategis BPS. Badan Pusat Statistik, Jakarta.
BPS. (2014). Produksi Jagung. Badan Pusat Statistik, Jakarta

Chaves, M. M., Maroco, J. P. \& Pereira, J. S. (2003). Understanding plant responses to droughtfrom genes to the whole plant. Functional Plant Biology, 30(3), 239-264.

Farooq, M., Wahid, A., Kobayashi, N., Fujita, D., \& Basra, S. M. A. (2009). Plant drought stress: effects, mechanisms and management. In Sustainable Agriculture, (pp. 153-188). Springer, Dordrecht.

Gomez, K. A., \& Gomez, A. A. (1984). Statistical Procedures for Agricultural Research. John Wiley \& Sons. New York.

Hakim, L. \& Sediyarsa, M. (1986). Percobaan perbandingan beberapa sumber pupuk fosfat alam di daerah Lampung Utara. hlm. 179-194. Dalam U. Kurnia, J. Dai, N. Suharta, I.P.G. Widjaya-Adhi, J. Sri Adiningsih, S.Sukmana, J. Prawira Sumantri (Ed.). Prosiding Pertemuan Teknis Penelitian Tanah, Cipayung, 10-13 November 1981. Pusat Penelitian Tanah, Bogor.

Lahuddin, L., Hardy, H., Sitorus, B., \& Yanti, R. A. (2013). Interaksi kompos dan dolomit: Efek interaksi perlakuan kompos dan dolomit pada tanah sangat asam terhadap kadar Ca-dd, Al-dd, dan P-Bray II dalam Tanah. Jurnal Ilmu Pertanian Kultivar, 4(2).32-36.

Mahmud, A., Guritno, B. \& Sudiarso. (2002). Pengaruh pupuk organik kascing dan tingkat pemberian air terhadap pertumbuhan dan hasil tanaman kedelai. Agrivita, 24(1). 37-43.

Mathius, N. T., Liwang, T., Danuwikarsa, M. I., Suryatmana, G., Djajasukanta, H., Saodah, D. \& Astika, I. G. P. W. (2004). Respons Biokimia Beberapa Progeni Kelapa Sawit (Elaeis guineensis Jacq.) Terhadap Cekaman Kekeringan Pada Kondisi Lapang. Balai Penelitian Bioteknologi Perkebunan Indonesia, Bogor.

Mokolobate, M. S., \& Haynes, R. J. (2002). Increases in $\mathrm{pH}$ and soluble salts influence the effect that additions of organic residues have on concentrations of exchangeable and soil solution aluminium. European Journal of Soil Science, 53 (3), 481-489.

Nafziger, E. (2011). High Temperatures and Crops. University of Illinois, USA.

Nasution, M.2004. Disertivikasi Titik Kritis Pembangunan Pertanian Mandiri. Penebar Swadaya, Jakarta 
Puslittanak. (2000). Atlas Sumberdaya Tanah Eksplorasi Indonesia Skala 1:1.000.000. Puslittanak. Badan Litbang Pertanian, Bogor.

Ridwan. (2000). Pengaruh Bahan Organik pada Tanaman Jagung di Lahan Alang-alang. Balai Pengkajian Teknologi Pertanian Sukarami, Jawa Barat.

Setyowati, N., Nurjanah, U. \& Korisma, R. (2009). Korelasi antara sifat-sifat tanah dengan hasil cabai merah pada subtitusi $\mathrm{N}$-organik dengan bokasi tusuk konde. J. Akta Agrosia, 12(2), 184-186.

Soepardi, G. (1983). Sifat dan Ciri Tanah. Departemen Tanah, Fakultas Pertanian, Institut Pertanian Bogor, Bogor.
Sumarwoto. (2004). Pengaruh pemberian kapur dan ukuran Bulbil terhadap pertumbuhan Ilesiles (Amorphophallus muelleri Blume) pada tanah ber-Al tinggi. Ilmu Pertanian, 11, 45-53.

Tambone, F., Scaglia, B., D’Imporzano, G., Schievano, A., Orzi, V., Salati, S. \& Adani, F. (2010). Assessing amendment and fertilizing properties of digestates from anaerobic digestion through a comparative study with digested sludge and compost. Chemosphere, 81(5), 577583.

Wayah, E., Sudiarso, S. \& Soelistyono, R. (2014). Pengaruh pemberian air dan pupuk kandang sapi terhadap pertumbuhan dan hasil tanaman jagung manis (Zea mays Saccharata Sturt L.). Jurnal Produksi Tanaman, 2(2), 94-102. 